\title{
Pengaruh Profitabilitas dan Kecukupan Modal terhadap Nilai Perusahaan dengan Islamic Social Report (ISR) sebagai Variabel Moderasi (Studi pada Bank Umum Syariah Indonesia Tahun 2014-2018)
}

\author{
Fauzi Sulistiyo $^{\left.1^{*}\right)}$, Indah Yuliana ${ }^{2)}$ \\ ${ }^{1 *, 2)}$ Fakultas Ekonomi, Universitas Islam Negeri Maulana Malik Ibrahim Malang \\ e-mail: fauzi.faeyza95@gmail.com ${ }^{1 *}$
}

\begin{abstract}
This study aims to prove the factors that influence the value of the company in Islamic commercial banks in Indonesia. Factors analyzed in this study are profitability, capital adequacy, and Islamic Social Report (ISR). The population in this study is the annual report of Islamic banks in Indonesia. The sample in this study used 8 Islamic commercial bank companies that met the criteria during the 2014-2018 period which were examined using the purposive sampling method. The method in this study uses regression analysis and moderation analysis. Based on the results of hypothesis testing it can be concluded that profitability, capital adequacy, and Islamic Social Report (ISR) have a positive effect on firm value. Then the Islamic Social Report (ISR) is able to moderate the relationship between profitability and capital adequacy to the value of the company
\end{abstract}

Keywords: profitability, capital adequacy, islamic social report, company value.

\begin{abstract}
Abstrak
Penelitian ini bertujuan untuk membuktikan faktor yang mempengaruhi nilai perusahaan pada bank umum syariah di Indonesia. Faktor yang dianalisis dalam penelitian ini adalah profitabilitas, kecukupan modal, dan Islamic Social Report(ISR). Populasi dalam penelitian ini adalah laporan tahunan bank umum syariah Indonesia. Sampel dalam penelitian ini menggunakan 8 perusahaan bank umum syariah yang memenuhi kriteria selama periode 2014-2018 yang diteliti menggunakan metode purposive sampling. Metode dalam penelitian ini menggunakan analisis regresi dan analisi moderasi. Berdasarkan hasil pengujian hipotesis dapat disimpulkan bahwa profitabilitas, kecukupan modal, dan Islamic Social Report (ISR) berpengaruh positif terhadap nilai perusahaan. Kemudian Islamic Social Report (ISR) mampu memoderasi hubungan antara profitabilitas dan kecukupan modal terhadap nilai perusahaan.
\end{abstract}

Kata Kunci: profitabilitas, kecukupan modal, islamic social report, nilai perusahaan.

\section{PENDAHULAN}

Pada era sekarang ini, bank syariah telah berkembang dengan pesat di Indonesia. Perkembangan ini dapat dilihat dari semakin banyaknya masyarakat yang tertarik untuk pindah dari bank konvensional ke bank syariah. Ketertarikan mayarakat tersebut dilatar belakangi karena bank syariah menawarkan konsep yang berbeda dari bank konvensional, yang mana dalam kegiatan transaksinya, bank syariah mencegah dan meminimalisir transakasi yang mengandung unsur-unsur riba. Kemudian, konsep keuntungan yang diberikan kepada nasabah bukan dengan memberikan bunga akan tetapi 
dengan konsep bagi hasil, dan prinsip kemitraan. Sehingga hal-hal tersebut yang membuat nasabah tertarik untuk berpindah ke bank syariah dan menjadi salah satu solusi alternatif terhadap persoalaan permasalahan perekonomian di Indonesia khususnya permasalahan dalam sistem keuangan nasional.

Bank syariah merupakan lembaga keuangan yang melandaskan kegiatannya berdasarkan prinsip syariah, atau prinsip hukum islam yang diatur dalam Majelis Ulama Indonesia, sehingga semua produk dan kegiatan operasional pada bank syariah harus menerapkan kaidah pada akad-akad dalam fiqih muamalah.Perkembangan perbankan syariah memberi pengaruh luas terhadap upaya perbaikan ekonomi umat dan kesadaran baru untuk mengadopsi lembaga keuangan Islam. Dengan adanya bank syariah juga, diharapkan dapat memberikan kemaslahatan bagi masyarakat dan memiliki kontribusi yang optimal bagi perekonomian. Hal tersebut sejalan dengan pernyataan Farook (2011) yang menyatakan bahwa filosofi di balik perbankan Islam bertujuan untuk membentuk distribusi keadilan bebas dari segala macam eksploitasi

Bank syariah yang didirikan berdasarkan prinsip-prinsip islam selain bertujuan untuk mendapatkan profit atau laba, tentu diharapkan dapat memaksimalkan nilai perusahaan dari bank syariah tersebut. Hal itu dikarenakan semakin tinggi nilai perusahaan, maka semakin tinggi kesejahteraan bagi pemilik dan pemegang saham perusahaan. Nilai perusahaan merupakan konsep penting bagi investor, karena merupakan indikator bagi pasar menilai perusahaan secara keseluruhan (Kusumadilaga dalam Fitriyah dkk, 2016). Nilai perusahaan merupakan cerminan dari penambahan dari jumlah ekuitas perusahaan (Mahendra dalam Fitriyah dkk, 2016 ). Sehingga optimalisasi nilai perusahaan sangat diperlukan, agar dapat meningkatkan kesejahteraan pemilik dan pemegang saham perusahaan.

Salah satu indikator yang digunakan untuk mengukur nilai perusahaan adalah dengan Price to Book Value (PBV). PBV adalah rasio yang digunakan untuk mengukur seberapa besar harga saham yang terdapat di pasar dibandingkan dengan nilai buku sahamnya (Fahmi, 2014). Semakin tinggi rasio PBV maka semakin tinggi pula nilai bagi pemegang saham, sehingga akan meningkatkan nilai perusahaan. Nilai perusahaan dapat dipengaruhi oleh beberapa faktor. Faktor-faktor tersebut dapat berasal dari faktor internal perusahaan maupun faktor eksternal perusahaan. Faktor-faktor internal perusahaan yang dapat mempengaruhi nilai perusahaan diantaranya profitabilitas, kecukupan modal.

Rasio Profitabilitas merupakan salah satu faktor yang dapat mempengaruhi nilai perusahaan. Rasio Profitabilitas merupakan rasio untuk menilai kemampuan perusahaan dalam mencari keuntungan dan juga memberikan ukuran tingkat efektivitas manajemen suatu perusahaan (Kasmir, 2010). Perusahaan yang dapat menghasilkan profit yang tinggi dan stabil, tentu akan menarik minat investor. Hal tersebut karena akan menguntungkan bagi pihak investor. Perusahaan yang mampu menghasilkan profit yang tinggi tentu memiliki manajemen perusahaan yang baik, sehingga dapat meningkatkan kepercayaan investor. Kepercayaan investor ini dapat menjadi alat yang efektif untuk meningkatkan harga saham perusahaan. Meningkatnya harga saham berarti meningkatkan nilai perusahaan, sehingga kedepannya dapat meningkatkan kesejahteraan pemegang saham. Dengan 
demikian, profitabilitas memiliki pengaruh yang besar bagi investor, oleh karena itu pihak perusahaan berusaha semaksimal mungkin untuk memperoleh profit yang tinggi (Lubis dkk, 2017). Semakin baik kinerja keuangan suatu perusahaan pasti semakin baik pula nilai perusahaannya (Triagustina, dalam Lubis dkk, 2017).

Profitabilitas dalam penelitian ini diproksikan dengan Return On Asset (ROA). Return On Asset (ROA) merupakan suatu pengukuran dari penghasilan setelah pajak yang tersedia bagi para pemilik perusahaan atas modal yang mereka investasikan dalam perusahaan. Sehingga, secara umum semakin tinggi return atau penghasilan yang diperoleh maka semakin baik kedudukan pemilik perusahaan dan juga nilai perusahaan (Syamsudin, 2007). Pernyataan tentang profitabilitas yang memiliki pengaruh terhadap nilai perusahaan didukung oleh penelitian Khoiriyah (2018) yang menunjukkan bahwa profitabilitas memiliki pengaruh positif dan siginifikan terhadap nilai perusahaan. Saidi (Lubis, dkk 2017) menyatakan bahwa profitabilitas sendiri merupakan kemampuan perusahaan dalam memperoleh laba.

Nilai perusahaan juga dipengaruhi oleh rasio kecukupan modal. Arifin (2002) menyatakan bahwa modal didefinisikan sebagai sesuatu yang mewakili kepentingan pemilik dalam suatu perusahaan. Modal merupakan faktor yang amat penting bagi perkembangan dan kemajuan bank sekaligus menjaga kepercayaan masyarakat. Setiap penciptaan aktiva, disamping berpotensi menghasilkan keuntungan juga berpotensi menimbulkan terjadinya risiko. Oleh karena itu, modal juga harus dapat digunakan untuk menjaga kemungkinan terjadinya risiko kerugian atas aktiva dan investasi pada aktiva, terutama yang berasal dari dana-dana pihak ketiga atau masyarakat. Peningkatan peran aktiva sebagai penghasil keuntungan harus secara simultan dibarengi dengan pertimbangan risiko yang mungkin timbul guna melindungi kepentingan para pemilik dana. Jika bank tersebut sudah beroperasi maka modal merupakan salah satu faktor yang sangat penting bagi pengembangan usaha dan menampung risiko kerugian Pernyataan tentang kecukupan modal yang memiliki pengaruh positif terhadap nilai perusahaan didukung oleh penelitian (Sari, 2018). Sedangkan penelitian yang dilakukan oleh Agustina (2014) yang menyatakan bahwa kecukupan modal berpengaruh negatif terhadap nilai perusahaan.

Dalam usaha untuk meningkatkan nilai perusahaan, diperlukan upaya dari perusahaan untuk mengungkapkan informasi mengenai aktivitas perusahaan. Pengungkapan informasi tersebut meliputi pengungkapan informasi atas aspek keuangan, lingkungan sosial dan lingkungan hidup. Ketika perusahaan melakukan pengungkapan informasi mengenai aktivitas perusahaan maka hal tersebut dapat meningkatkan kepercayaan pengguna dan mempertahankan kesuksesan perusahaan. Hal tersebut seperti yang diungkapkan Othman et.al, (2010) dalam teori stakeholders yang menyatakan bahwa manajamen yang membagikan informasi perusahaan kepada pengguna dapat meningkatkan kepercayaan stakeholders dan mempertahankan kesuksesan perusahaan. Stakeholders sendiri merupakan pihak atau kelompok yang memiliki kepentingan, baik kepentingan secara langsung maupun tidak langsung di dalam aktivitas perusahaan. Sehingga stakeholders memiliki peran yang 
penting dalam perusahaan tersebut.

Pengungkapan informasi atau laporan mengenai aktivitas perusahaan salah satunya dapat mengacu pada Islamic Social Report (ISR). Islamic Social Report (ISR) pertama kali dikemukakan oleh Haniffa (2002) yang menyatakan bahwa dalam pelaporan tanggung jawab sosial perusahaan pada sistem konvensional hanya berfokus pada aspek material dan moral, sehingga ia menambahkan bahwa aspek spiritual juga harus dijadikan fokus dalam pelaporan tanggung jawab sosial. Oleh karena itu, pelaporan tanggung jawab sosial perusahaan harus disesuaikan dengan prinsip Islam, sehingga selain dapat membantu pengambilan keputusan bagi pihak muslim, juga dapat membantu perusahaan dalam memenuhi kewajibannya terhadap Allah Subhannaahu wa Ta'ala dan masyarakat.

Islamic Social Report (ISR) merupakan bentuk pengungkapan mengenai pengembangan tanggung jawab sosial yang telah memasukkan nilai-nilai atau prinsip-prinsip syariah (Savira, 2015). Islamic Social Report terdiri dari kumpulan item-item standar Corporate Social Responsibility (CSR) yang ditetapkan oleh AAOIFI (Accounting and Auditing Organizing for Islamic Financial) yang dikembangkan, sehingga didalamnya terkandung prinsip-prinsip islam yang digunakan sebagai pengungkapan tanggung jawab sosial dalam suatu entitas islam (Fitriyah, dkk 2016). Islamic Social Report (ISR) lebih menekankan terhadap keadilan sosial dalam pelaporan tanggung jawab sosial perusahaan, selain pelaporan terhadap lingkungan, kepentingan minoritas dan karyawan Widiawati dan Surya (2012). Kemudian dengan adanya konsep Islamic Social Reporting (ISR) diharapkan memberikan suatu alternatif kontribusi yang baru bagi pelaporan perusahaan secara islami dan bisa menjadi suatu jembatan antara dunia dan akhirat untuk meningkatkan kesadaran manusia pada kegiatan duniawi yang terkait dengan kehidupan di akhirat nanti (Setiawan, dkk 2018).

Indeks Islamic Social Reporting (ISR) juga diyakini mampu menjadi tumpuan awal mengenai standar dalam pengungkapan pelaporan informasi aktivitas perusahaan terutama dalam pelaporan sosial yang sesuai dengan perspektif islam. Ketika perusahaan melakukan pengungkapan informasi sosial maka investor akan tertarik untuk menanamkan modalnya. Hal tersebut seperti yang diungkapkan Eipstein dan Freedman (Anggraini, 2006) yang menemukan bahwa investor akan tertarik terhadap pengungkapan informasi sosial yang dilaporkan dalam laporan tahunan. Ketika investor tertarik untuk menanamkan modalnya dalam suatu perusahaan, maka hal tersebut dapat meningkatkan nilai perusahaan yang dapat dilihat dari meningkatnya nilai ROA dalam perusahaan tersebut. Pernyataan tentang Islamic Social Report (ISR) yang memiliki pengaruh positif terhadap nilai perusahaan didukung oleh penelitian Setiawan dkk, (2018). Sedangkan penelitian yang dilakukan oleh Sutapa dan Heri Laksito (2018) menyatakan bahwa Islamic Social Report (ISR) tidak berpengaruh terhadap nilai perusahaan. 


\section{TINJAUAN PUSTAKA}

\section{Profitabilitas Terhadap Nilai Perusahaan}

Kinerja suatu perusahaan dapat dilihat dari profitabilitas perusahahan tersebut, semakin tinggi profitabilitasnya maka semakin tinggi pula kemampuan perusahaan dalam menghasilkan keuntungan. Rasio profitabilitas yang tinggi, tentu akan membuat para investor tertarik untuk menginvestasikan modalnya ke dalam perusahaan tersebut. Besar kecilnya laba suatu perusahaan akan mempengaruhi nilai perusahaan, sehingga akan menimbulkan hubungan yang positif antara profitabilitas dengan harga saham, yang mana kemudian tingginya harga saham akan berpengaruh terhadap nilai perusahaan. Penelitian yang dilakukan oleh Sutrisno (2014), Lubis, dkk (2017), membuktikan bahwa profitabilitas berpengaruh positif terhadap nilai perusahaan.

Rasio ROA digunakan sebagai indikator dalam mengukur keberhasilan perusahaan untuk memperoleh laba bagi para pemegang saham, sehingga dari pemaparan diatas dapat diperoleh hipotesis sebagai berikut:

H1 : Profitabilitas berpengaruh terhadap nilai perusahaan.

\section{Kecukupan Modal Terhadap Nilai Perusahaan}

Modal merupakan faktor yang amat penting bagi perkembangan dan kemajuan bank sekaligus menjaga kepercayaan masyarakat. Setiap penciptaan aktiva, disamping berpotensi menghasilkan keuntungan juga berpotensi menimbulkan terjadinya risiko. Menurut Arifin (2002) modal didefinisikan sebagai sesuatu yang mewakili kepentingan pemilik dalam suatu perusahaan. Dalam penelitian yang dilakukan oleh Halimah dan Komariah (2017), dan Sari (2018), membuktikan bahwa kecukupan modal berpengaruh positif terhadap nilai perusahaan. Dari pemaparan diatas maka diperoleh hipotesis sebagai berikut :

H2 : Kecukupan modal berpengaruh terhadap nilai perusahaan.

\section{Pengaruh Islamic Social Reporting Terhadap Nilai Perusahaan}

Islamic Social Reporting adalah suatu pengungkapan tentang tanggung jawab sosial perusahaan yang telah dikembangkan, dimana di dalamnya telah dimasukkan nilai-nilai atau prinsip-prinsip Islam. Islamic Social Reporting umumnya digunakan untuk mengungkapkan laporan pertanggung jawaban suatu entitas Islam. Dalam upaya untuk meningkatkan nilai perusahaan khususnya dalam perbankan syariah, salah satu cara yang dapat dilakukan dengan mengungkapkan informasi mengenai aktivitas perusahaan kepada stakeholders. Ketika perusahaan melakukan pengungkapan informasi aktivitas perusahaan atau tanggung jawab sosial kepada stakeholders maka hal tersebut dapat meningkatkan kepercayaan stakeholders. Hal tersebut seperti yang diungkapkan dalam teori stakeholders yang menyatakan bahwa manajamen yang mengungkapkan informasi tentang aktivitas perusahaan dapat meningkatkan kepercayaan stakeholders dan mempertahankan kesuksesan perusahaan, sehingga diharapkan nantinya dapat meningkatkan nilai perusahaan juga (Othman dan Tani, 2010). 
Dalam penelitian yang dilakukan oleh Setiawan (2018), Rahayu (2013), membuktikan bahwa Islamic Social Reporting berpengaruh positif terhadap nilai perusahaan. Dari pemaparan diatas maka diperoleh hipotesis sebagai berikut :

H3 : Islamic Social Reporting berpengaruh terhadap nilai perusahaan.

\section{Profitabilitas Terhadap Nilai Perusahaan dengan Islamic Social Reporting Sebagai Variabel Moderasi.}

Semakin baik pengungkapan Islamic Social Reporting suatu perusahaan, maka semakin baik pula nilai perusahaan dimata investor, karena pertanggungjawaban mengenai aktivitas perusahaan tersebut berjalan seimbang, baik pertanggungjawaban kepada Allah (akuntabilitas vertikal), dan pertanggungjawaban kepada manusia dan alam (akuntabilitas horizontal). Hal tersebut nantinya akan meningkatkan kepercayaan dan minat investor untuk berinvestasi dan meningkatkan nilai perusahaan.

Kemudian dengan didukung profitabilitas yang baik maka akan memberikan dampak yang baik juga terhadap pengungkapan Islamic Social Reporting. Seperti penyataan yang diungkapkan oleh Watts and Zimmerman (1986), perusahaan yang memiliki profit yang tinggi, akan cenderung melakukan intervensi kebijakan. Sehingga, perusahaan tersebut akan terpacu untuk mengungkapkan informasi yang lebih rinci dalam laporan keuangan perusahaan. Penelitian terdahulu yang yang dilakukan oleh Haniffa and Cooke (2005) dan Othman et. Al, (2009), Irmawati (2018) membuktikan bahwa profitabilitas berpengaruh positif terhadap tingkat pengungkapan Islamic Social Reporting. Dengan demikian, maka diperoleh hipotesis sebagai berikut :

H4 : Islamic Social Reporting dapat memoderasi hubungan antara profitabilitas terhadap nilai perusahaan.

\section{Kecukupan Modal Terhadap Nilai Perusahaan dengan Islamic Social Reporting Sebagai Variabel Moderasi.}

Rasio kecukupan modal yang sering disebut dengan Capital Adequacy Ratio (CAR) mencerminkan kemampuan bank untuk menutup risiko kerugian dari aktivitas yang dilakukannya dan kemampuan bank dalam mendanai kegiatan operasionalnya (Idroes, 2008). Ketika bank mampu meningkatkan cadangan kas yang dapat digunakan untuk mendanai kegiatan operasionalnya, maka akan membuka peluang yang lebih besar bagi bank untuk meningkatkan rentabilitasnya. Jika rentabilitasnya bagus maka keuangan perusahaan dalam keadaan yang sehat. Tentu hal tersebut dapat meningkatkan kepercayaan investor untuk menanamkan modalnya.

Kemudian menurut Astuti (2019) tingkat kecukupan modal pada bank syariah menjadi salah satu pertimbangan yang penting bagi bank syariah dalam melakukan pengungkapan Islamic Social Report (ISR). Jika kecukupan modal bank syariah baik maka bank akan lebih melakasanakan Islamic Social (ISR) yang juga akan meningkatkan pengungkapan pada laporan tahunannya. Kecukupan modal diduga berpengaruh terhadap Islamic Social Reporting. Hal tersebut sesuai dengan penelitian 
yang dilakukan oleh Zuhdi, (2015), Rosfina (2018), Sulastiningsih dan Rizka (2018) yang menunjukkan bahwa kecukupan modal berpengaruh terhadap pengungkapan tanggung jawab sosial secara islam atau Islamic Social Reporting.

H5 : Islamic Social Reporting dapat memoderasi hubungan antara kecukupan modal terhadap nilai perusahaan.

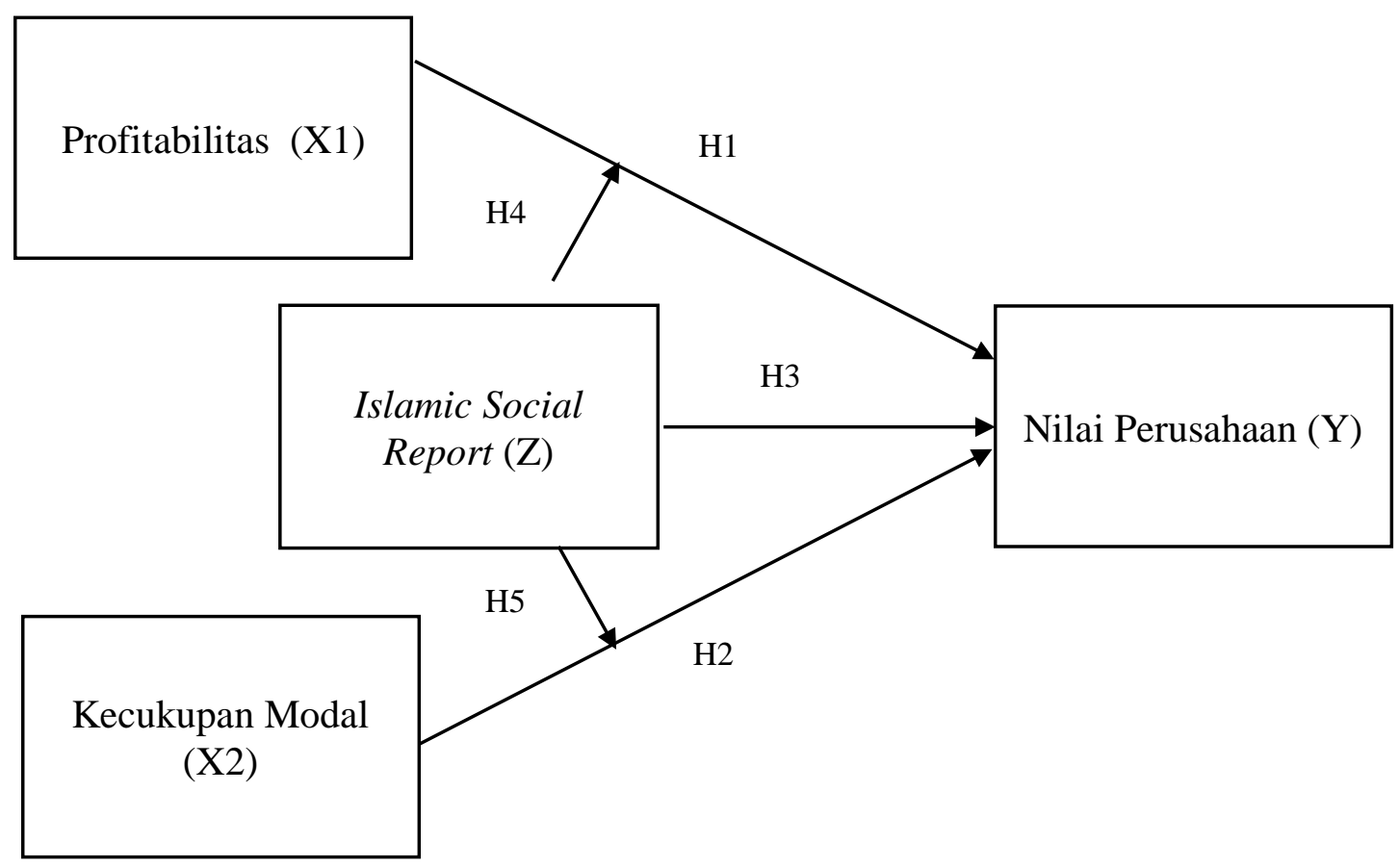

Gambar 1. Kerangka Penikiran

Sumber: Data diolah peneliti, 2019

\section{METODE PENELITIAN}

\section{Populasi dan Sampel}

Populasi dalam penelitian ini adalah seluruh Bank Umum Syariah di Indonesia pada tahun 2014 sampai 2018 dengan periode pengamatan 5 tahun. Teknik pengumpulan data dalam penelitian ini menggunakan purposive sampling, dengan kriteria sebagai berikut

1. Bank Umum Syariah yang beroperasi secara nasional dan terdaftar di Bank Indonesia.

2. Bank Umum Syariah yang beroperasi secara nasional dan berturut-turut selama periode penelitian 2014-2018.

3. Bank Umum Syariah yang menerbitkan laporan tahunan dan CSR secara berturut-turut selama periode penelitian 2014-2018.

4. Bank Umum Syariah yang tidak mengalami kerugian secara berturut-turut selama periode penelitian 2014-2018

Dari pembahasan kriteria tersebut maka sampel yang diperoleh adalah sebanyak 8 perusahaan bank umum syariah yang memenuhi kriteria. 


\section{Metode Analisis Data}

Analisis data yang dilakukan yaitu dengan analisis deskriptif. Kemudian uji asumsi klasik yang dilakukan yaitu uji normalitas, uji linieritas, uji multikolineritas, uji autokorelasi, uji heteroskedastisitas. Serta uji hipotesis yang dilakukan yaitu uji T (T-Test) dan juga uji Moderated Regression Analysis (MRA) dengan menggunakan bantuan SPSS 16.

Adapun bentuk model persamaan regresi dalam penelitian ini adalah :

$\mathrm{Yi}=\alpha+\beta 1 \mathrm{X} 1+\beta 2 \mathrm{X} 2+\beta 3 \mathrm{Zi}+\beta 4 \mathrm{X} 1 * \mathrm{Zi}+\beta 5 \mathrm{X} 2 * \mathrm{Zi}$

Keterangan :

$\mathrm{Yi}=$ Nilai Perusahaan

$\mathrm{X} 1=$ Profitabilitas

$\mathrm{X} 2$ = Kecukupan modal

$\mathrm{Zi}=$ Islamic Social Reporting (ISR)

$\mathrm{X} 1 * \mathrm{Zi}=$ Interaksi antara profitabilitas dengan ISR

$\mathrm{X} 2 * \mathrm{Zi}=$ Interaksi antara kecukupan modal dengan ISR

$\alpha=$ parameter konstanta

$\beta 1, \beta 2, \beta 3, \beta 4, \beta 5=$ Koefisien regresi berganda

\section{HASIL DAN PEMBAHASAN}

\section{Statistik Deskriptif}

Statistik deskriptif memberikan gambaran atau deskripsi suatu data yang dilihat dari nilai ratarata (mean), standard deviasi, varian, maksimum, minimum, sum, range, kurtosis dan skewness (Ghozali, 2013). Analisis deskriptif digunakan untuk menggambarkan dan mendeskripsikan variabelvariabel yang digunakan dalam penelitian ini. Analisis deskriptif dilakukan dengan menggunakan statistik deskriptif yang menghasilkan nilai rata-rata, maksimum, minimum, dan standar deviasi untuk mendeskripsikan variabel penelitian sehingga secara kontekstual mudah dimengerti.

\section{Tabel 2}

Descriptive Statistics

\begin{tabular}{|l|r|r|r|r|r|}
\hline & \multicolumn{1}{|c|}{$N$} & Minimum & Maximum & \multicolumn{1}{c|}{ Mean } & Std. Deviation \\
\hline Profitabilitas & 40 & .0002 & .1240 & .017022 & .0286457 \\
Kecukupan_Modal & 40 & .1234 & .4090 & .201707 & .0701679 \\
Nilai_Perusahaan & 40 & .9854 & 5.1883 & $1.9627 \mathrm{E} 0$ & 1.1206959 \\
Islamic_Social_Report & 40 & .5100 & .9000 & .710750 & .1033884 \\
Valid N (listwise) & 40 & & & & \\
\hline
\end{tabular}

Sumber: data diolah peneliti, 2019

Dari Tabel 2 dapat dilihat mengenai nilai minimum, nilai maksimum, nilai mean, dan standar deviasi semua variabel penelitian dari tahun 2014 sampai tahun 2018.

1) Profitabilitas bank umum syariah memiliki nilai maksimum yaitu sebesar 0,1240 dan nilai minimum yaitu sebesar 0,002, dengan nilai rata-rata (mean) sebesar 0,17022. dan standar deviasi 
adalah sebesar 0,0286457. Dari pemaparan data statistik deskriptif diatas, diketahui bahwa indeks profitablitas sebagai variabel independen (bebas) terbebas dari outlier (data pencilan).

2) Kecukupan Modal bank umum syariah memiliki nilai maksimum yaitu sebesar 0,4090, dan nilai minimum yaitu sebesar 0,1234, dengan nilai rata-rata (mean) sebesar 0,201707. dan standar deviasi adalah sebesar 0,0701679. Dari pemaparan data statistik deskriptif diatas, diketahui bahwa indeks kecukupan modal sebagai variabel independen (bebas) terbebas dari outlier (data pencilan).

3) Nilai Perusahaan bank umum syariah memiliki nilai maksimum yaitu sebesar 5,1883, dan nilai minimum yaitu sebesar 0,9854, dengan nilai rata-rata (mean) sebesar 1,9627E0. dan standar deviasi adalah sebesar 1,1206959. Dari pemaparan data statistik deskriptif diatas, diketahui bahwa indeks Nilai Perusahaan sebagai variabel dependen (terikat) terbebas dari outlier (data pencilan).

4) Islamic Social Report bank umum syariah memiliki nilai maksimum yaitu sebesar 0,9000, dan nilai minimum yaitu sebesar 0,5100, dengan nilai rata-rata (mean) sebesar 0,710750 dan standar deviasi adalah sebesar 0,1033884. Dari pemaparan data statistik deskriptif diatas, diketahui bahwa indeks Islamic Social Report sebagai variabel moderasi terbebas dari outlier (data pencilan).

\section{Uji Asumsi Klasik}

\section{Uji Normalitas}

Uji Normalitas bertujuan untuk menguji apakah dalam model regresi, variabel pengganggu atau residual memiliki distribusi normal. Model regresi yang baik adalah yang memiliki nilai residual yang berdistribusi secara normal (Priyatno, 2017:109), Dalam penelitian ini, uji normalitas ini dilakukan dengan pendekatan Kolmogorov-Smirnov. Kriteria dalam pengujian normalitas data menggunakan uji Kolomogorv Smirnov (K-S) yaitu apabila nilai signifikansi > 0,05, maka data tersebut ditolak dan sebaliknya jika nilai signifikansi < 0,05 maka data dikatakan tidak normal.

Tabel 3

Uji Kolmogorov Smirnov Test

One-Sample Kolmogorov-Smirnov Test

\begin{tabular}{|ll|r|}
\hline & & $\begin{array}{c}\text { Unstandardiz } \\
\text { ed Residual }\end{array}$ \\
\hline N & Mean & 40 \\
Normal Parameters & & .0000000 \\
Most Extreme Differences & Std. Deviation & .86006761 \\
& Absolute & .180 \\
& Positive & .180 \\
Kolmogorov-Smirnov $Z$ & Negative & $-.075-$ \\
Asymp. Sig. (2-tailed) & & 1.136 \\
\end{tabular}

a. Test distribution is Normal.

Sumber : data diolah peneliti, 2019

Berdasarkan Tabel 3 di atas dapat dilihat bahwa data dalam penelitian ini berdistribusi secara normal. Hal tersebut karena nilai signifikansi (Asymp. Sig 2-tailed) sebesar 0,151. Atau nilai tersebut lebih besar dari 0,05. Sehingga uji normalitas terpenuhi. 


\section{Uji Linieritas}

Uji linieritas digunakan untuk mengetahui apakah dua variabel mempunyai huungan yang liniear atau tidak secara signifikan. Uji ini umumnya dipakai untuk prasyarat dalam analisis korelasi atau regresi linear. Pengujian pada SPSS dengan menggunakan nilai Deviation from Linearity Sig. dengan taraf signifikansi 0,05. Dua variabel dikatakan memiliki hubungan yang liniear jika signifikansi lebih dari 0,05.

Tabel 4

ANOVA Table

\begin{tabular}{|c|c|c|c|c|c|c|c|}
\hline & & & $\begin{array}{c}\text { Sum of } \\
\text { Squares }\end{array}$ & $\mathrm{df}$ & Mean Square & $\mathrm{F}$ & Sig. \\
\hline \multirow{5}{*}{$\begin{array}{l}\text { Nilai_Perusahaan * } \\
\text { Profitabilitas }\end{array}$} & \multirow[t]{3}{*}{ Between Groups } & (Combined) & 45.746 & 33 & 1.386 & 2.570 & .119 \\
\hline & & Linearity & 6.011 & 1 & 6.011 & 11.145 & .016 \\
\hline & & Deviation from Linearity & 39.735 & 32 & 1.242 & 2.302 & .150 \\
\hline & \multicolumn{2}{|l|}{ Within Groups } & 3.236 & 6 & .539 & & \\
\hline & \multicolumn{2}{|l|}{ Total } & 48.982 & 39 & & & \\
\hline
\end{tabular}

Sumber: data diolah peneliti, 2019

Dari Tabel 4 diatas yang merupakan variabel profitabilitas diketahui bahwa nilai Deviation from Linearity Sig. 0,150 lebih besar dari 0,05. Sehingga dapat disimpulkan bahwa ada hubungan linear secara signifikan antara profitabilitas terhadap nilai perusahaan.

Tabel 5

\begin{tabular}{|c|c|c|c|c|c|c|c|}
\hline \multicolumn{8}{|c|}{ ANOVA Table } \\
\hline & & & $\begin{array}{c}\text { Sum of } \\
\text { Squares }\end{array}$ & df & Mean Square & $\mathrm{F}$ & Sig. \\
\hline \multirow{5}{*}{$\begin{array}{l}\text { Nilai_Perusahaan * } \\
\text { Kecukupan_Modal }\end{array}$} & \multirow[t]{3}{*}{ Between Groups } & (Combined) & 48.809 & 38 & 1.284 & 7.392 & .285 \\
\hline & & Linearity & .837 & 1 & .837 & 4.815 & .272 \\
\hline & & Deviation from Linearity & 47.972 & 37 & 1.297 & 7.462 & .284 \\
\hline & \multicolumn{2}{|l|}{ Within Groups } & .174 & 1 & .174 & & \\
\hline & \multicolumn{2}{|l|}{ Total } & 48.982 & 39 & & & \\
\hline
\end{tabular}

Sumber: data diolah peneliti, 2019

Dari Tabel 5 dapat dilihat yang merupakan variabel kecukupan modal diketahui bahwa nilai Deviation from Linearity Sig. 0,284 lebih besar dari 0,05. Sehingga dapat disimpulkan bahwa ada hubungan linear secara signifikan antara kecukupan modal terhadap nilai perusahaan.

\section{Tabel 6}

\begin{tabular}{|c|c|c|c|c|c|c|c|}
\hline \multicolumn{8}{|c|}{ ANOVA Table } \\
\hline & & & $\begin{array}{c}\text { Sum of } \\
\text { Squares }\end{array}$ & df & Mean Square & $\mathrm{F}$ & Sig. \\
\hline \multirow{5}{*}{$\begin{array}{l}\text { Nilai_Perusahaan * } \\
\text { Islamic_Social_Report }\end{array}$} & \multirow[t]{3}{*}{ Between Groups } & (Combined) & 27.919 & 16 & 1.745 & 1.905 & .077 \\
\hline & & Linearity & 3.064 & 1 & 3.064 & 3.345 & .080 \\
\hline & & Deviation from Linearity & 24.855 & 15 & 1.657 & 1.809 & .097 \\
\hline & \multicolumn{2}{|l|}{ Within Groups } & 21.064 & 23 & .916 & & \\
\hline & \multicolumn{2}{|l|}{ Total } & 48.982 & 39 & & & \\
\hline
\end{tabular}

Sumber: data diolah peneliti, 2019

Dari Tabel 6 yang merupakan variabel Islamic Social Report (ISR) diketahui bahwa nilai Deviation from Linearity Sig. 0.097 lebih besar dari 0.05. Sehingga dapat disimpulkan bahwa ada hubungan linear secara signifikan antara islamic social report terhadap nilai perusahaan. 


\section{Uji Multikolinieritas}

Uji multikolinieritas merupakan uji yang memiliki tujuan untuk mengetahui apakah dalam model regresi ditemukan adanya korelasi antar variabel independen (bebas). Model regresi yang baik merupakan model regresi yang tidak terjadi korelasi diantara variabel independen (bebas). Peneliti menggunakan nilai variance factor (VIF) dalam pengujian ini. Uji multikolinieritas terpenuhi jika angka VIF tidak melebihi 10 (Ghozali, 2016 :103).

\section{Tabel 7}

\section{Uji Multikolinieritas}

Coefficients ${ }^{2}$

\begin{tabular}{|c|c|c|c|c|c|c|c|c|}
\hline \multirow{2}{*}{\multicolumn{2}{|c|}{ Madel }} & \multicolumn{2}{|c|}{ Unstandardized Coefficients } & \multirow{2}{*}{$\begin{array}{c}\begin{array}{c}\text { Standardized } \\
\text { Coefficients }\end{array} \\
\text { Beta } \\
\end{array}$} & \multirow[b]{2}{*}{$t$} & \multirow[b]{2}{*}{ Siq. } & \multicolumn{2}{|c|}{ Collinearity Statistics } \\
\hline & & B & Std. Error & & & & Tolerance & VIF \\
\hline \multirow[t]{4}{*}{1} & (Constant) & $-.533-$ & 1.285 & & $-.415-$ & .681 & & \\
\hline & Profitabilitas & 28.557 & 6.209 & .730 & 4.599 & .000 & .649 & 1.540 \\
\hline & Kecukupan_Modal & $-6.117-$ & 2.455 & $-.383-$ & $-2.492-$ & .017 & .693 & 1.444 \\
\hline & Islamic_Social_Report & 4.563 & 1.538 & .421 & 2.967 & .005 & .813 & 1.231 \\
\hline
\end{tabular}

a. Dependent Variable: Nilai_Perusahaan

Sumber: data diolah peneliti, 2019

Berdasarkan Tabel Coefficients diatas menunjukkan bahwa semua variabel memiliki nilai VIF kurang dari 10, sehingga tidak terjadi multikolinieritas antar variabel independen dalam moderasi regresi.

\section{Uji Autokorelasi}

Uji autokorelasi merupakan uji yang bertujuan untuk mengetahui apakah model regresi liniear ada korelasi antara anggota observasi yang disusun menurut waktu dan tempat. Model regresi yang baik adalah ketika tidak terjadi autokorelasi (Priyatno, 2017: 123). Peneliti menggunakan uji DurbinWatsom (DW test).

Berdasarkan hasil uji autokorelasi diatas diperoleh nilai dw sebesar 1.404 kemudian dibandingkan dengan nilai tabel durbin watson $(\mathrm{dw})$ dengan jumlah observasi $(\mathrm{n})=40$, jumlah independen $(\mathrm{k})=3$ dan tingkat signifikansi 0,05 di dapat nilai $\mathrm{dl}=1,34$, dan nilai $\mathrm{du}=1,66$. Maka asumsi tidak terjadinya autokorelasi terpenuhi.

\section{Uji Heteroskedastisitas}

Uji Heteroskedastisitas merupakan uji yang bertujuan untuk mengetahui apakah dalam model regresi terjadi kesamaan varian dari residual suatu pengamatan ke pengamatan lain. Apabila varian dari residual suatu pengamatan ke pengamatan lain tetap, maka disebut homoskedastisitas dan jika berbeda disebut heteroskedastisitas. Moder regresi yang baik yaitu yang homoskedastisitas dan tidak terjadi heteroskedastisitas (Priyatno, 2017).

Peneliti menggunakan uji koefisien korelasi Spearman's rho, yaitu mengkorelasikan antara absolute residual hasil regresi dengan semua variabel bebas. Data dikatakan signifikan apabila hasil 
korelasi lebih besar dari 0,05 (5\%), yang berarti persamaan regresi tersebut bebas dari heteroskedastisitas dan begitupun sebaliknya yang berarti homoskedastisitas. Dibawah ini adalah tabel dari uji heteroskedastisitas sebagai berikut :

Tabel 9

Hasil Uji Heteroskedastisitas

\begin{tabular}{lllr} 
& & Abs_res \\
\hline Spearman's rho & profitabilitas & Correlation Coeffcient & -.048 \\
& & Sig. (2-tailed) & .219 \\
& $\mathrm{~N}$ & 40 \\
\hline & Kecukupan & Correlation Coeffcient & -.314 \\
& Modal & Sig. (2-tailed) & .495 \\
& N & 40 \\
& Islamic Social & Correlation Coeffcient & .232 \\
\hline Report & Sig. (2-tailed) & .702 \\
\hline
\end{tabular}

Sumber: Data SPPS yang diolah oleh peneliti, 2019

Dari tabel di atas menunjukkan bahwa variabel profitabilitas, kecukupan modal, islamic social report yang di uji memiliki nilai korelasi yang lebih besar dari 0,05. Sehingga dapat dikatakan bahwa semua variabel tersebut terbebas dari heteroskedastisitas atau bisa disebut homoskedastisitas.

\section{Analisis Statistik}

Tabel 10. Hasil Analisis Statistik

\begin{tabular}{lrrr}
\hline Variabel & B & \multicolumn{1}{c}{ t } & \multicolumn{1}{c}{ Sig. t } \\
\hline Konstanta & $-17,764-$ & $-4,965-$ & 0,000 \\
ROA & 352,621 & 4,023 & 0,000 \\
CAR & 72,074 & 3,271 & 0,002 \\
ISR & 28,810 & 5,795 & 0,000 \\
\hline Adjusted R. Square $=$ & 0.740 & & \\
\hline
\end{tabular}

Sumber: Data SPPS yang diolah oleh peneliti, 2019

\section{Koefisien Determinasi}

Koefisien determinasi digunakan untuk mengetahui seberapa besar kemampuan variabel bebas dalam menerapkan variabel berikut. Nilai determinasi ditentukan dengan nilai adjusted $R$ Square.

Dari Tabel 10, dapat diketahui bahwa nilai adjusted $R$ Square adalah 0,740, hal tersebut menunjukkan bahwa kemampuan menjelaskan variabel independen yang diproksikan oleh ROA, CAR, dan ISR terhadap variabel dependen yaitu PBV sebesar 74\%, sedangkan sisanya 36\% dijelaskan oleh variabel lain diluar variabel independen tersebut. 


\section{Pengujian Hipotesis}

\section{Uji t (t-Test)}

Uji $\mathrm{T}$ ini digunakan untuk mengetahui signifikan atau tidaknya pengaruh variabel bebas terhadap variabel terikat secara individual dengan tingkat kepercayaan 95 persen dan tingkat kesalahan 5 persen. Menurut Ghozali (2016) dalam pengujian statistik jenis ini terdapat beberapa kriteria sebagai berikut:

1. Jika $\mathrm{t}$ hitung $>\mathrm{t}$ tabel maka terdapat pengaruh variabel independen (bebas) terhadap variabel dependen (terikat)

2. Jika signifikansi t lebih kecil dari taraf nyata (5\%) maka terdapat pengaruh variabel independen (bebas) terhadap variabel dependen (terikat).

Berdasarkan Tabel 10, dapat di ambil kesimpulan bahwa:

1. Hipotesis 1 : Profitabilitas berpengaruh terhadap nilai perusahaan.

Pengujian hipotesis yang pertama bertujuan untuk mengetahui pengaruh dari profitabilitas terhadap nilai perusahaan. Dari hasil uji t-test dapat dilihat bahwa nilai t hitung $(4,023)>\mathrm{t}$ tabel $(2,026)$, signifikannya kurang dari 0,05 dan betanya positif. Maka profitabilitas berpengaruh secara signifikan dan positf terhadap nilai perusahaan. Sehingga pada penelitian ini H1 diterima.

2. Hipotesis 2 : Kecukupan Modal berpengaruh terhadap nilai perusahaan.

Pengujian hipotesis yang kedua bertujuan untuk mengetahui pengaruh dari kecukupan modal terhadap nilai perusahaan. Dari hasil uji t-test dapat dilihat bahwa nilai t hitung $(3,271)>t$ tabel $(2,026)$, signifikannya kurang dari 0,05 dan betanya positif. Maka kecukupan modal berpengaruh secara signifikan dan positif terhadap nilai perusahaan. Sehingga pada penelitian ini H2 diterima.

3. Hipotesis 3 : Islamic Social Report (ISR) berpengaruh terhadap nilai perusahaan.

Pengujian hipotesis yang ketiga bertujuan untuk mengetahui pengaruh dari Islamic Social Report (ISR) terhadap nilai perusahaan. Dari hasil uji t-test dapat dilihat bahwa nilai t hitung $(5,795)>t$ tabel (2,026), signifikannya kurang dari 0,05 dan betanya positif. Maka Islamic Social Report (ISR) berpengaruh secara signifikan dan positf terhadap nilai perusahaan. Sehingga pada penelitian ini H3 diterima.

\section{Uji Moderasi}

Pengaruh Profitabilitas Terhadap Nilai Perusahaan dengan Islamic Social Reporting Sebagai Variabel Moderasi.

Dari hasil output SPSS pada Tabel 10 dapat dilihat bahwa signifikansinya kurang dari 0,05. Sehingga variabel Islamic Social Report (ISR) berinteraksi dengan (variabel independen) profitabilitas yang diproksikan dengan ROA dan berinterasksi dengan variabel (variabel dependen) nilai perusahaan yang diproksikan dengan PBV. Maka Islamic Social Report (ISR) merupakan variabel quasi moderator (moderator semu) dan H4 diterima. 


\section{Pengaruh Profitabilitas Terhadap Nilai Perusahaan dengan Islamic Social Reporting Sebagai Variabel Moderasi.}

Dari hasil output SPSS pada Tabel 10 dapat dilihat bahwa signifikansinya kurang dari 0,05. Sehingga variabel Islamic Social Report (ISR) berinteraksi dengan (variabel independen) kecukupan modal yang diproksikan dengan CAR dan berinterasksi dengan variabel (variabel dependen) nilai perusahaan yang diproksikan dengan PBV. Maka Islamic Social Report (ISR) merupakan variabel quasi moderator (moderator semu) dan H5 diterima.

\section{Pembahasan}

\section{Pengaruh Profitabilitas terhadap Nilai Perusahaan}

Berdasarkan hasil yang diperoleh dari pengujian regresi menggunakan uji t-test dapat dilihat bahwa nilai t hitung $(4,023)>\mathrm{t}$ tabel $(2,026)$, signifikannya kurang dari 0,05 dan betanya positif. Maka profitabilitas berpengaruh secara signifikan dan positf terhadap nilai perusahaan. Sehingga pada penelitian ini H1 diterima. Hasil penelitian ini tidak sejalan dengan penelitian terdahulu Thaib, I dan Acong, D (2017) dan (Padli dkk, 2019). Namun hasil penelitian ini sejalan dengan penelitian terdahulu yang dilakukan oleh Sutrisno (2014), MHD Rajab (2017), Lubis, dkk (2017), Raharjo, S., dan Wahyuni, S. (2019) yang menyatakan bahwa profitabilitas berpengaruh positif terhadap nilai perusahaan.

\section{Pengaruh Kecukupan Modal Berpengaruh terhadap Nilai Perusahaan}

Berdasarkan hasil yang diperoleh dari pengujian regresi menggunakan uji t-test dapat dilihat bahwa nilai $\mathrm{t}$ hitung $(3,271)>\mathrm{t}$ tabel $(2,026)$, signifikannya kurang dari 0,05 dan betanya positif. Maka kecukupan modal berpengaruh secara signifikan dan positf terhadap nilai perusahaan. Sehingga pada penelitian ini H2 diterima. Hasil penelitian ini tidak sejalan dengan penelitian terdahulu Nugroho, A (2015), (Maimunah dan Fahtiani 2019). Namun hasil penelitian ini sejalan dengan penelitian terdahulu yang dilakukan oleh Halimah dan Komariah (2017), Sari (2018), yang menyatakan bahwa kecukupan modal berpengaruh positif terhadap nilai perusahaan.

\section{Pengaruh Islamic Social Report (ISR) Berpengaruh terhadap Nilai Perusahaan}

Berdasarkan hasil yang diperoleh dari pengujian regresi menggunakan uji t-test dapat dilihat bahwa nilai t hitung $(5,795)>t$ tabel $(2,026)$, signifikannya kurang dari 0,05 dan betanya positif. Maka Islamic Social Report (ISR) berpengaruh secara signifikan dan positf terhadap nilai perusahaan. Sehingga pada penelitian ini H3 diterima. Hasil penelitian ini tidak sejalan dengan penelitian terdahulu Fitriyah, dkk (2016), (Setiyani N, 2019). Namun hasil penelitian ini sejalan dengan penelitianpenelitian terdahulu yang dilakukan oleh Rahayu (2013), Iwan dkk (2018), yang menyatakan bahwa Islamic Social Report (ISR) berpengaruh positif terhadap nilai perusahaan. 


\section{Pengaruh Profitabilitas Terhadap Nilai Perusahaan dengan Islamic Social Reporting Sebagai} Variabel Moderasi

Berdasarkan pengujian moderasi menggunakan SPSS, dapat dilihat bahwa signifikansinya kurang dari 0,05. Sehingga variabel Islamic Social Report (ISR) berinteraksi dengan (variabel independen) profitabilitas yang diproksikan dengan ROA dan berinterasksi dengan (variabel dependen) nilai perusahaan yang diproksikan dengan PBV. Maka Islamic Social Report (ISR) merupakan variabel quasi moderator (moderator semu) dan H4 diterima. Hasil penelitian ini tidak sejalan dengan penelitian terdahulu Ramadhani (2016). Namun hasil penelitian ini sejalan dengan penelitian-penelitian terdahulu yang dilakukan oleh Haniffa and Cooke (2005) dan Othman et. Al, (2009). Sutapa dan Laksito (2018).

\section{Pengaruh Kecukupan Modal Terhadap Nilai Perusahaan dengan Islamic Social Reporting Sebagai Variabel Moderasi}

Berdasarkan pengujian moderasi menggunakan SPSS, dapat dilihat bahwa signifikansinya kurang dari 0,05. Sehingga variabel Islamic Social Report (ISR) berinteraksi dengan (variabel independen) kecukupan modal yang diproksikan dengan CAR dan berinterasksi dengan (variabel dependen) nilai perusahaan yang diproksikan dengan PBV. Maka Islamic Social Report (ISR) merupakan variabel quasi moderator (moderator semu) dan H5 diterima. Hasil penelitian ini tidak sejalan dengan penelitian terdahulu Masrurroh dan Ade (2017). Namun hasil penelitian ini sejalan dengan penelitian-penelitian terdahulu yang dilakukan oleh Zuhdi, (2015), Rosfina (2018)

\section{KESIMPULAN DAN SARAN}

\section{Kesimpulan}

Berdasarkan hasil analisis dan pembahasan yang telah dijelaskan pada bab sebelumnya, maka dapat ditarik kesimpulan sebagai berikut:

1. Profitabilitas berpengaruh positif terhadap nilai perusahaan. Hal ini disebabkan profitabilitas merupakan indikator dalam mengukur kinerja keuangan suatu perusahaan. Meningkatknya profit akan meningkatkan daya tarik investor untuk menanamkan modalnya karena perusahaan tersebut memperoleh keuntungan yang tinggi, sehingga hal tersebut akan meningkatkan nilai perusahaan.

2. Kecukupan modal berpengaruh positif terhadap nilai perusahaan, Hal ini disebabkan jika CAR tinggi maka masyarakat dan investor akan percaya terhadap kemampuan permodalan bank, dan mereka akan menginvestasikan modalnya, dengan meningkatnya modal tersebut maka dapat meningkatkan kinerja perusahaan, sehingga nanti dapat meningkatkan nilai perusahaan.

3. Islamic Social Reporting berpengaruh positif terhadap nilai perusahaan. Hal ini disebabkan bank umum syariah mampu memberikan informasi mengenai pengungkapan tanggung jawab sosial perusahaan secara islami dalam laporan tahunan untuk meningkatkan kepercayaan stakeholders 
terhadap sistem syariah yang berlaku dalam perusahaan, sehingga mampu meningkatkan nilai perusahaan.

4. Islamic Social Reporting mampu memoderasi hubungan profitabilitas terhadap nilai perusahaan, yang mana moderasinya memperkuat hubungan profitabilitas terhadap nilai perusahaan. Ketika stakeholders percaya terhadap perbankan syariah. Maka mereka akan bersedia untuk mengivestasikan modalnya, modal tersebut jika dikelola secara efektif dan efisien maka akan menghasilkan keuntungan yang besar. Dengan semakin meningkatnya keuntungan, maka dapat meningkatkan nilai perusahaan.

5. Islamic Social Reporting mampu memoderasi hubungan kecukupan modal terhadap nilai perusahaan, yang mana moderasinya memperkuat hubungan kecukupan modal terhadap nilai perusahaan. Ketika perusahaan melakukan pengungkapan tanggung jawab sosial perusahaan secara islami kepada stakeholders, maka hal tersebut dapat meningkatkan kepercayaan stakeholders dan mereka akan bersedia untuk mengivestasikan modalnya ke bank umum syariah. Ketika modal bank umum syariah meningkat, maka hal tersebut dapat meningkatkan kinerja keuangannya, sehingga dapat meningkatkan nilai perusahaan bank umum syariah.

\section{Saran}

Bagi masyarakat yang akan menginvestasikan uangnya kepada bank umum syariah, maka harus memperhatikan aspek-aspek yang ada dalam bank umum syariah tersebut. Jangan hanya melihat dari sisi profitabilitas yang akan diperoleh, tetapi juga tujuan syariah dan kepedulian sosial dari perusahaan tersebut. Hal ini disebabkan perusahaan dalam meningkatkan nilai tidak hanya dari segi profitabilitas saja, namun juga dari aspek yang lain.

Bagi perbankan syariah diharapkan untuk memperhatikan aspek-aspek penting yang ada dalam perusahaan, agar keberlangsungan perusahaan terus terjaga, dan supaya investor lebih tertarik untuk menginvestasikan modalnya ke dalam perbankan syariah. Dan bagi penelitian selanjutnya yang memiliki kesamaan tema, dapat menambahkan variabel-variabel penting lainnya yang dapat berpengaruh signifikan terhadap nilai perusahaan. Agar dapat kedepannya dapat diketahui faktorfaktor apa saja yang dapat meningkatkan nilai perusahaan.

\section{REFERENSI}

Agustina, LAA. 2014. Pengaruh CAR, NPL, NIM, LDR, dan BOPO terhadap Nilai Perusahaan dengan ROA sebagai Variabel Intervening pada Bank-Bank Umum Go Public di Indonesia Periode 2008-2012. Skripsi. Jurusan Manajemen Fakultas Ekonomika dan Bisnis Universitas Diponegoro Semarang.

Anggraini, Fr. R. Retno. 2006. Pengungkapan Informasi Sosial dan Faktor-faktor yang Mempengaruhi Pengungkapan Informasi Sosial dalam Laporan Keuangan Tahunan. Simposium Nasional Akuntansi 9 Padang. Universitas Sanata Dharma Yogyakarta.

Arifin, Z. 2002. Dasar-Dasar Manajemen Perbankan Syariah. Jakarta: Alfabeta.

Astuti, S. 2019. Analisis Faktor-faktor yang Mempengaruhi Pengukuran Pengungkapan Corporate Social Responsibility (CSR) Perbankan Syariah Berdasarkan Indeks Islamic Social Report 
(ISR). Jurnal Akuntansi dan Manajemen Akmenika. Vol. 16. No. 1. Hal: 162-174.

Brigham and Houston. 2010. Dasar-Dasar Manajemen Keuangan. Buku 1. Edisi 11. Jakarta: Salemba Empat.

Dendawijaya, L. 2009. Manajemen Perbankan. Jakarta: Ghalia Indonesia

Fahmi, I. 2014. Manajemen Keuangan Perusahaan dan Pasar Modal. Jakarta: Mitra Wacana Media.

Farook, S., Kabir HM., dan Lanis, R. 2011. Determinants of corporate social responsibility disclosure: the case of Islamic banks. Journal of Islamic Accounting and Business Research. Vol. 2. No. 2. Hal: 114-141.

Fitriyah, N., Alamsyah., Pusparini, H. 2016. Kinerja Keuangan dalam Kerangka Maqoshid Syariah: Pengaruhnya terhadap Nilai Perusahaan dengan Islamic Social Reporting sebagai Variabel Moderating. Jurnal Aksioma, Vol. 15. No. 2. Hal: 72-95.

Ghozali, I. 2013. Aplikasi Analisis Multivariate dengan Program IBM SPSS 21. Semarang Universitas Diponegoro.

Ghozali, I. 2016. Aplikasi Analisis Multivariate dengan Program IBM SPSS 23. Semarang: Universitas Diponegoro.

Halimah, SN., dan Komariah, Euis. 2017. Pengaruh ROA, CAR, NPL, LDR, BOPO terhadap Nilai Perusahaan Bank Umum. Jurnal Akuntansi, Ekonomi dan Manajemen Bisnis. Vol. 5. No. 1. Hal: $14-25$

Haniffa, R. 2002. Social reporting disclosure. an islamic prespective. Indonesian Management and Accounting Research I. Vol. 1. No. 2. Ha: 128-146.

Haniffa, R.M., and Cooke, T. E. 2005. The Impact of Culture and Givernance on Corporate Social Reporting. Journal of Accounting and Public Policy, Vol. 24. Hal: 391-430.

Idroes, F. 2008. Manajemen Risiko Perbankan. Jakarta: PT. Raja Grafindo Persada.

Irmawati. 2018. Analisis Faktor-faktor yang Mempengaruhi Tingkat Pengungkapan Islamic Social Reporting pada Bank Umum Syariah di Indonesia. Skripsi. Fakultas Ekonomi dan Bisnis Universitas Hasanuddin Makassar.

Kasmir. 2010. Analisis Laporan Keuangan. Jakarta: PT. Raja Grafindo Persada.

Khoiriyah, N. 2018. Pengaruh Ukuran Perusahaan dan Profitabilitas terhadap Nilai Perusahaan dengan Kebijakan Deviden sebagai Variabel Pemoderasi. Skripsi. Jurusan Manajemen Fakultas Ekonomi Universitas Islam Negeri (UIN) Maulana Malik Ibrahim Malang.

Lubis, IL., Sinaga, BM., Sasongko, H. 2017. Pengaruh Profitabilitas, Sruktur Modal, dan Likuiditas terhadap Nilai Perusahaan. Jurnal Aplikasi Bisnis dan Manajemen. Vol. 3. No. 3. Hal: 458465.

Maimunah, S., dan Fahtiani, T. 2019. Pengaruh NPL, ROA, dan CAR Terhadap PBV pada Bank BUMN. Jurnal Informasi Perpajakan, Akuntansi, dan Keuangan Publik. Vol. 14. No. 1. Hal: 19-36.

Masrurroh, D.A., dan Ade, S.M. 2017. Analisa Pengaruh Size Perusahaan, CAR, NPL, ROA, FDR terhadap Pengungkapan Corporate Social Responsibility (CSR) Bank Umum Syariah di Indonesia Periode 2012-2015. Vol. 4. No. 1. Hal: 1-18.

Nugroho, A. 2015. Pengaruh Kecukupan Modal, Risiko Kredit, Profitabilitas dan Kebijakan Dividen terhadap Nilai Perusahaan. Skripsi. Fakultas Ekonomi dan Bisnis Universitas Muhammadiyah Yogyakarta.

Othman, R., and Thani, Azlan, Md. 2010. Islamic Social Reporting of Listed Companies In Malaysia. Jurnal International Business \& Economics Research. Vol. 9. No. 4. Hal: 135-144.

Padli, MI., Diana, N., dan Afifudin. 2019. Pengaruh Good Corporate Governance, Maqashid Sharia, dan Profitabilitas terhadap Nilai Perusahaan. E-JRA. Vol. 8. No. 1. Hal: 1-13.

Priyatno, D. 2017. Panduan Praktis Olah Data Menggunakan SPSS. Yogyakarta: ANDI.

Raharjo, S., dan Wahyuni, S. 2019. Analisis Pengaruh Pembiayaan Murabahah dan Mudharabah terhadap Nilai Perusahaan dengan Profitabilitas sebagai Variabel Intervening. Jurnal Bisnis \& Manajemen. Vol. 19. No. 1. Hal: 39-50.

Rahayu, T. 2013. Pengaruh Pengungkapan Islamic Social Reporting (Indeks ISR) terhadap Nilai Perusahaan. Skripsi. Program Studi Keuangan Islam Fakultas Syariah dan Hukum Universitas Islam Negeri Sunan Kalijaga Yogyakarta. 
Rajab, MHD. 2017. Pengaruh Profitabilitas terhadap Nilai Perusahaan dengan Corporate Social Responsibility sebagai Variabel Moderating. Skripsi. Jurusan Ekonomi Islam Fakultas Ekonomi dan Bisnis Islam Universitas Islam Negeri Sumatera Utara Medan.

Ramadhani, F. 2016. Pengaruh Ukuran Perusahaan, Profitabilitas, Leverage dan Ukuran Dewan Pengawas Syariah terhadap Pengungkapan Islamic Social Reporting. JOM Fekon. Vol. 3. No. 1. Hal: 2487-2500.

Rodoni, A, dan Herni. 2014. Manajemen Keuangan Modern. Jakarta: Mitra Wacana Media.

Rosfina, A. 2018. Analisis Pengaruh Financial Performance dan Denda (Ta'zir) terhadap Pengungkapan Islamic Social Reporting pada Bank Umum Syariah di Indonesia Tahun 20132016. Skripsi. Program Studi Ekonomi Syariah Fakultas Ekonomi dan Bisnis Universitas Islam Negeri Syarif Hidayatullah Jakarta.

Sari, PY. 2018. Pengaruh Kinerja Keuangan dan Corporate Social Responsibility (CSR) terhadap Nilai Perusahaan pada Bank yang Terdaftar di Bursa Efek Indonesia Periode 2011-2015. Jurnal Nominal. Vol. 7. No. 1. Hal: 111-125.

Savira, MN. 2015. Pengaruh Ukuran Perusahaan, Ukuran Dewan Komisaris, Ukuran Dewan Pengawas Syariah, Crossdirectorship, Kepemilikan Manajerial, dan Kepemilikan Institusional Terhadap Pengungkapan Islamic Social Reporting (ISR). Skripsi. Jurusan Akuntansi Fakultas Ekonomi Universitas Negeri Semarang.

Setiawan, I., Swandari, F., Dewi, DM. 2018. Pengaruh Pengungkapan Islamic Social Reporting (ISR) terhadap Nilai Perusahaan dengan Kinerja Keuangan sebagai Variabel Moderating. Jurnal Wawasan Manajemen. Vol. 6. No. 2. Hal: 168-186.

Setiyani, N. 2019. Pengaruh Profitabilitas dan Pengungkapan Islamic Social Reporting (ISR) Terhadap Nilai Perusahaan pada Bank Panin Dubai Syariah TBK Periode 2016-2018. Thesis. Fakultas Ekonomi dan Bisnis Islam IAIN Purwokerto.

Sulastiningsih dan Rizka, I.S. 2018. Pengaruh Kinerja Keuangan dan Corporate Social Responsibility (CSR) terhadap Nilai Perusahaan Perbankan di Bursa Efek Indonesia. Jurnal Kajian Bisnis. Vol. 26. No. 1. Hal: 95-111.

Sutapa., Laksito, H. 2018. Peran Islamic Social Reporting terhadap Nilai Perusahaan. Jurnal Akuntansi Indonesia. Vol. 7. No. 1. Hal: 57-68.

Sutrisno. 2014. Pengaruh Profitabilitas terhadap Kebijakan Dividen dan Nilai Perusahaan. Business and Management Journal Bunda Mulia. Vol. 10. No. 2. Hal: 32-48.

Syamsudin, L. 2007. Manajemen Keuangan Perusahaan. Jakarta: PT Raja Grafindo Persada.

Thaib, I. dan Acong, D. 2017. Pengaruh Profitabilitas dan Likuiditas terhadap Nilai Perusahaan dengan Struktur Modal sebagai Variabel Intervening. Jurnal Riset Perbankan Manajemen dan Akuntansi. Vol. 10. No. 1. Hal: 25-44.

Watts, RL., and Zimmerman, JL. 1986. Positive Accounting Theory. USA: Prentice-Hall.

Widiawati, S dan Surya, R. 2012. Analisis Faktor-faktor yang Mempengaruhi Islamic Social Reporting (ISR) Perusahaan-Perusahaan yang Terdapat pada Daftar Efek Syariah Tahun 20092011. Diponegoro Journal of Accounting. Vol. 1. No. 2. Hal: 1-15.

Yuliati, Erna dan Zakaria. 2015. Analisis Risk, Earnings dan Capital Terhadap Nilai Perusahaan pada Perusahaan Perbankan yang Terdaftar di Bursa Efek Indonesia Tahun 2010-2014. Jurnal Future. Hal: 108-124.

Zuhdi, M.A. 2015. Analisis Pengaruh Good Corporate Governance dan Kinerja Keuangan terhadap Pengungkapan Islamic Social Reporting. Skripsi. Fakultas Ekonomi Universitas Muhammadiyah Yogyakarta. 